\begin{tabular}{lcr}
\hline \multicolumn{1}{c}{ A N N A L E S } \\
UNIVERSitatis & MARIAE CURIE-SKŁODOWSKA \\
LUBLIN - POLONIA & 2020 \\
\hline
\end{tabular}

Uniwersytet Kazimierza Wielkiego w Bydgoszczy, Wydział Nauk o Polityce i Administracji

\author{
MARTYNA RAJEK-KWIATEK
}

ORCID ID: 0000-0001-7273-3084

\title{
Partycypacja i inkluzja społeczna jako wymiary polityki rewitalizacji miejskiej
}

Participation and Social Inclusion as a Dimension of Urban Regeneration Policy

\begin{abstract}
ABSTRAKT
W artykule poruszono kwestię społecznego aspektu rewitalizacji, która winna być procesem złożonym, uwzględniającym w każdym z jego stadiów szeroko rozumiany współudział społeczeństwa lokalnego. Stymulowanie tego procesu w celu aktywizacji, animacji i integracji jest swoistą specyfiką odnowy miast, ale też prawem obywatelskim i procedurą obowiązującą w państwach demokratycznych. W warunkach polskich miast - mimo uchwalonej w 2015 roku Ustawy o rewitalizacji - opracowane postanowienia społecznego aspektu w dalszym ciągu budzą wiele wątpliwości. W związku z tym, przyjmując metodę analityczną, autorka rozpocznie rozważania od nakreślenia istoty procesów rewitalizacyjnych i wskazania optymalnej jej zdaniem definicji. W dalszej części przybliży zagadnienie „partycypacji społecznej”, ustosunkowując się do koncepcji local governance jako modelu popularyzującego zaufanie, społeczeństwo obywatelskie i kapitał społeczny. Wskazana zostanie też słuszność zasady włączenia społecznego jako prymatu procesów rewitalizacyjnych. Uzupełniająco zinterpretuje uwarunkowania polskiej polityki rewitalizacji miejskiej w zakresie aktywizacji społecznej, analizując jakość przepisów prawnych zawartych w Ustawie o rewitalizacji i wykorzystywanych w praktyce narzędzi. Umożliwi to zdiagnozowanie poziomu realnych działań na rzecz uspołecznienia procesów rewitalizacyjnych, jak też wytyczenia perspektywicznych zabiegów w celu udoskonalenia pożądanych rezultatów. W podsumowaniu zaś stwierdzi, iż obligatoryjne jest wypracowanie nowego kierunku polityki rewitalizacji miejskiej, której największym mankamentem w polskich realiach jest przede wszystkim stosowanie biernych metod aktywizujących oraz ograniczenie upodmiotowienia społeczności miejskich.
\end{abstract}

Słowa kluczowe: rewitalizacja, przestrzeń miejska, partycypacja, współuczestnictwo, inkluzja społeczna 


\section{WSTĘP}

Procesy rewitalizacji polskich miast z początku XXI wieku cechowały się brakiem podstaw planistycznych, organizacyjnych i finansowych, a samo pojęcie rewitalizacji było określeniem dość enigmatycznym. Znaczna część podjętych inwestycji sprowadzała się bowiem do modernizacji śródmiejskich dzielnic w celach turystycznych bądź do tzw. „elewacyzacji” budynków, co niejako było konsekwencją pozyskiwania dostępnych funduszy unijnych w myśl niedoprecyzowanej definicji [Górski 2018: 29-30]. Podejmowane wówczas działania przyczyniły się do podziału polskich przestrzeni miejskich według ich atrakcyjności inwestycyjnej, a w efekcie - do powstania tzw. „miast dualnych". Z upływem czasu proces polaryzacji przestrzeni miast zaczął generować wiele negatywnych zjawisk społecznych, tj. ubóstwo i wykluczenie społeczne, zły stan infrastruktury i pogarszające się warunki mieszkalne, wzrost przestępczości, deficyt usług, niski poziom edukacji i/lub kapitału społecznego, jak również niewystarczający poziom uczestnictwa w życiu publicznym i kulturalnym [Przywojska 2016: 12-13]. Dopiero wówczas problemy przestrzenne i funkcjonalne oraz postępująca degradacja przestrzeni miejskiej pozwoliły dostrzec, iż obligatoryjne jest wypracowanie nowych idei, które umożliwią prawidłowy ich rozwój. Nade wszystko dostrzeżono konieczność wypracowania jednej podstawowej definicji traktującej rewitalizację jako kompleksowy proces organizacyjno-inwestycyjny [Parysek 2016a: 6]. W wyniku powstałej debaty opartej na doświadczeniach zagranicznych i krajowych wypracowano nowy model myślenia o mieście, w tym także nowe podejście do procesu rewitalizacji jako istotnego komponentu odnowy przestrzeni miast ${ }^{2}$. W myśl tych refleksji dostrzeżono konieczność percypowania rewitalizacji jako ewolucji społecznej generującej niedostrzegalne do tej pory (a obowiązkowe w rewitalizacji) zmiany postrzegania danej przestrzeni, jej włączenia

1 „Miasta dualne” (dual cities) bądź teoria dualizacji miast została szerzej opisana przez polskiego socjologa A. Majera [2011: 33]. Autor wskazał, iż jest to bezpośredni skutek niewspółmierności wynikający z awansu ekonomicznego danej zbiorowości mieszkańców i pauperyzacji innych grup społeczności miejskiej. Proces ten nie tylko pogłębia dystans ekonomiczny i kulturowy między dwiema klasami społeczeństwa, ale powoduje swoiste zjawisko gettoizacji przestrzeni miejskiej. W dalszej kolejności skutkować to może licznymi konfliktami społecznymi czy pogłębiającą się degradacją takiego miasta.

2 Odnosząc się do nowego modelu myślenia o mieście, autorka ma na uwadze europejskie strategie odnowy miast, których wdrożenie stało się konieczne w wyniku skutków urbanizacji i rewolucji przemysłowej z XIX wieku. Powstałe wówczas zmiany znacząco wpłynęły na kształt współczesnych przestrzeni miast, przyczyniając się do pogorszenia warunków życia w mieście, a w dalszej kolejności - degradacji śródmiejskich dzielnic i ich opustoszenia. $Z$ tego też względu dostrzeżono konieczność ożywienia i uatrakcyjnienia współczesnych miast, zwiększenia bezpieczeństwa i poprawę jakości życia. W tym celu wypracowano model odnowy miast europejskich, który uwzględnia założenia wielu koncepcji, m.in. nowego urbanizmu (new urbanism), inteligentnego rozwoju (smart growth) czy rozwoju zrównoważonego. Model ten traktuje w sposób równoważny cele techniczne, przestrzenne, społeczne, kulturowe, ekologiczne i gospodarcze [Majer 2014: 57]. Z kolei nowe podejście do procesu rewitalizacji to nade wszystko podnoszenie znaczenia kwestii społecznych, a także promowanie zintegrowanego podejścia i działań na rzecz trwałości efektów działań rewitalizacyjnych. 
w strukturę funkcjonalną miasta, a więc zmiany jej społecznego obrazu [Górski 2018: 30-31]. Wymaga to bezspornego udziału wszystkich interesariuszy, w tym także i przede wszystkim - mieszkańców rewitalizowanego terenu. W związku z tym proces rewitalizacji winien polegać na umiejętnym łączeniu przemian urbanistycznych ze zmianami społecznymi i ekonomicznymi, tak by odnawialne przestrzenie nabrały nowych cech witalnych. Integralnymi elementami współczesnej polityki rewitalizacyjnej stało się zatem pojęcie partycypacji oraz zasada inkluzji społecznej.

Niniejszy artykuł przedstawia szczegółowe omówienie społecznych aspektów rewitalizacji, dowodzących zasadność aktywizacji społeczności lokalnych w procesach odnowy miast. Tym samym należy zaznaczyć, iż artykuł ten wpisuje się w nurt badawczy poświęcony idei współrządzenia. W opracowaniu przyjęto dwa wiodące cele. Pierwszy to przybliżenie istoty i znaczeń pojęć ,,partycypacji” oraz ,inkluzji społecznej”, w których za istotę przyjmuje się otwartość współuczestników rewitalizacji oraz konieczność rozumienia potrzeb i oczekiwań wszystkich mieszkańców. Drugi zaś to wytypowanie kluczowych barier, które w polskiej rzeczywistości powodują, iż potencjalnie znane instrumenty partycypacji i społecznego włączenia często stają się martwe. Tak zdefiniowany zakres opracowania wskaże cenne wskazówki dla praktyków zajmujących się uspołecznianiem rewitalizacji względem efektywnego rozwiązywania problemów degradacji, gentryfikacji oraz dysfunkcji polskich przestrzeni miejskich.

\section{REWITALIZACJA W ROZWAŻANIACH TEORETYCZNYCH}

Termin „rewitalizacja” nierzadko traktowany jest zamiennie z innymi określeniami związanymi z szeroko rozumianą „naprawą” przestrzeni miast. Również w literaturze anglojęzycznej, gdzie można natrafić na takie określenia, jak regeneracja (regeneration), odnowa (renewal), rehabilitacja (rehabilitation), rekonstrukcja (reconstruction), ponowny rozwój (redevelopment) czy nawet gentryfikacja. Każde $\mathrm{z}$ nich jest specyficznym znaczeniem rewitalizacji w poszczególnych okresach, tj. rekonstrukcja w latach 50. XX wieku, rewitalizacja w 60., odnowa w 70., ponowny rozwój w latach 80., zaś w latach 90 . była to regeneracja. Gentryfikację należy zaś rozumieć jako proces osiedlania się wyższych klas społecznych po dokonanej rewitalizacji w miejscach dotychczas zamieszkiwanych przez mieszkańców z uboższych warstw społecznych [Jadach-Sepioło 2007: 66]. Co więcej, również w Ustawie o planowaniu i zagospodarowaniu przestrzennym z 2003 roku, która z uwagi na brak dokumentu dotyczącego rewitalizacji stanowiła wówczas podstawowy w jej zakresie akt prawny, występowało pojęcie „rehabilitacji” rozumianej przez ustawodawcę jako synonim rewitalizacji [Parysek 2016b: 18-19]. Jak wskazuje powyższe, sens semantyczny pojęcia ,rewitalizacja” jest dość obszerny, dlatego też na potrzeby niniejszego opracowania należy wskazać definicję właściwą z punktu widzenia autorki.

Współcześnie dokonywana odnowa miast polskich, z uwagi na ilość zdegradowanych przestrzeni i budynków stanowiących kumulację wielu problemów społecz- 
nych, jednoznacznie kojarzona jest z procesem rewitalizacji. Zagadnienie to staje się przedmiotem zainteresowania nie tylko samorządów lokalnych, ale też społeczności miejskich czy mediów. Wśród czynników upowszechniających należy wskazać dynamizację negatywnych zjawisk miejskich oraz napływ funduszy europejskich, jak również konieczność uatrakcyjniania przestrzeni polskich miast. Do tej pory, jak wskazano we wstępie, rewitalizacją określano działania, które niekoniecznie miały z nią wiele wspólnego. Wśród najczęściej podejmowanych zabiegów były remonty, modernizacje czy rewaloryzacje ${ }^{3}$. Natomiast „rewitalizacja”4 jest pojęciem bardziej kompleksowym, spajającym powyższe działania z obligatoryjnym dla rewitalizacji działaniem na rzecz ożywienia społeczno-gospodarczego. Jej cele zależne są od przedmiotu, którego dotyczą, a więc od uwarunkowań, jakie występują w danym mieście. Z reguły są to działania urbanistyczno-architektoniczne, techniczne, społeczno-ekonomiczne i/lub środowiskowe ${ }^{5}$. Co istotne w procesach rewitalizacyjnych - muszą być to zabiegi interdyscyplinarne i wielowymiarowe, w których w celu powodzenia projektu niezbędna jest integracja wszystkich wymiarów działań: planistyczno-projektowych, organizacyjno-finansowych i promocyjno-informacyjnych [Lorens 2013: 58-62]. W związku z tym - mimo bogatej literatury przedmiotu w zakresie rewitalizacji i licznych jej definicji - w celu niniejszego opracowania przyjmuje się, iż rewitalizacja jest kompleksowym i tworzonym świadomie długo-

3 Pojęcie remontu oznacza przywrócenie stanu budynku bądź całego zespołu zabudowy do stanu ich pierwotnej użyteczności. Modernizacje zaś są remontami uzupełnionymi o dodatkowe ulepszenia i usprawnienia, które podnoszą komfort eksploatacji. Natomiast rewaloryzacja to nic innego jak przywrócenie wartości danego obiektu, a więc jest to remont lub modernizacja nadająca szczególnej wartości architektonicznej, zabytkowej bądź użytkowej. Więcej na ten temat w pracach K. Skalskiego, m.in. O budowie systemu rewitalizacji dawnych dzielnic miejskich; Rewitalizacja dawnych dzielnic miejskich; O budowie metod rewitalizacji w Polsce-aspekty wybrane, a także na stronie stowarzyszenia Forum Rewitalizacji: http:/www.forumrewitalizacji.pl/artykuly/ 16/38/Rewitalizacja-na-tle-innych-pojec.

4 Pojęciem zamiennym w niniejszym artykule będzie termin „odnowa miast”, niemniej uzupełniająco należy dodać, iż jest to pojęcie znacznie szersze. Postępujący dziś proces odradzania się miast bez wątpienia jest koniecznym warunkiem, mającym na celu odwrócenie negatywnych procesów miejskich. Wśród tych zjawisk należy nadmienić wiele różnorodnych zmian, tj. postępującą suburbanizację i rozlewanie się miast, pustoszenie i degradację śródmiejskich dzielnic, prywatyzację, fragmentaryzację czy gettyzację przestrzeni miejskiej, powstały chaos przestrzenny, brak atrakcyjnej przestrzeni publicznej dla mieszkańców i użytkowników, pogarszające się warunki życia w miastach itd. Z tego też względu w proces odnowy należy wliczyć także rewitalizację zdegradowanych przestrzeni stanowiących znaczącą barierę dla dalszych procesów rozwojowych. Proces rewitalizacji stanowi bowiem odpowiedź na współczesny kryzys miast, ale dotyczy obszarów o silnej koncentracji problemów rozwojowych. Ukształtowanie nowoczesnych przestrzeni będących efektem rewitalizacji umożliwia bowiem wzrost atrakcyjności i konkurencyjności danego miasta, a efektem synergetycznym winien być dalszy jego rozwój w sferze społecznej, gospodarczej i przestrzennej. Niemniej rewitalizację można postrzegać jako jeden z elementów procesu odnowy miast [Stawasz 2017: 253-261].

5 J. Parysek wskazał, iż w celu uzyskania zamierzonych efektów przedsięwzięć rewitalizacyjnych należy w trakcie jej charakterystyki, planowania i realizacji uwzględnić wiele istotnych elementów. Za najważniejsze uznał kwestie prawne, organizacyjne, ekonomiczne, społeczne, urbanistyczno-architektoniczne, środowiskowe, przestrzenne, techniczne i technologiczne. Podkreślił również, że mimo wielu wymienionych aspektów zestawienie to z pewnością nie jest zbiorem zamkniętym [Parysek 2015: 12]. 
trwałym procesem organizacyjno-inwestycyjnym polegającym na jednoczesnej realizacji działań naprawczych w wymiarze społecznym, przestrzenno-funkcjonalnym, kulturowym i gospodarczym. W efekcie końcowym generującym trwałe ożywienie zdegradowanej, zaniedbanej bądź dysfunkcyjnej przestrzeni miejskiej nadrzędnym celem jest przywrócenie jej wartości społecznej, a więc dostosowanie tej przestrzeni do potrzeb i oczekiwań jej mieszkańców. Ostatecznym następstwem zaś winna być jej akceptacja społeczna, doświadczanie i użytkowanie [Kaczmarek 2015: 28]. Uzupełniająco należy też wskazać, że remonty, modernizacje techniczne infrastruktury czy też nadawanie miejscom funkcji są jedynie środkami rewitalizacji, nie zaś jej celami [Krajowa Polityka Miejska: 56]. Oprócz tego, systematyzując pojęcie rewitalizacji, warto zapoznać się z wymogami pomyślnego przebiegu tego procesu, zgodnego ze współczesnym jego rozumieniem. Modelowy zbiór kluczowych zasad dla warunków polskich (określając je pryncypiami rewitalizacji) sporządził Jerzy Parysek [2016a: 8]. Autor wskazał 20 głównych zasad porządkujących interpretację pojęcia, wśród których znalazły się wytyczne związane z celem i zakresem tego procesu, prawidłowym jego projektowaniem i wdrażaniem, wskazaniem jego uczestników - inwestorów i beneficjentów, jak też wyznaczeniem obowiązków władz lokalnych. Zważając jednak na cel artykułu, kluczowym jest ostatni z punktów, który przedstawiono we wspomnianym zbiorze zasad. Autor wskazał bowiem, iż: „Podstawową zasadą podejmowania i realizacji zadań rewitalizacyjnych powinna być ich racjonalność ogólnospołeczna, co zagwarantować może jedynie dobrze pomyślane i faktyczne, uspołecznienie procesów rewitalizacji. Rewitalizacja, z uwagi na liczne i różnej natury problemy w jej prowadzeniu, wymaga stworzenia właściwego klimatu, skupienia wokół rewitalizacji jak najszerszych rzesz społeczności lokalnej oraz skutecznego rozwiązywania pojawiających się, w ramach podejmowanych działań, problemów społecznych oraz konfliktów przestrzennych".

\section{ZNACZENIE PARTYCYPACJI W POLITYCE REWITALIZACJI MIEJSKIEJ}

Partycypacja społeczna rozumiana jako „udział obywateli w zarządzaniu sprawami społeczności, której są członkami” [Hausner 1999: 41] odgrywa coraz większą rolę w procesach rządzenia miastami. Jest to zagadnienie relatywnie nowe, niemniej wzrost aktywności społeczeństwa stanowi podstawę funkcjonowania państwa demokratycznego. Co więcej, zdaniem Waldemara Siemińskiego, partycypację społeczną należy rozpatrywać jako wynik jednej z faz rozwoju demokracji formułowanej jako „demokracja rozwinięta” bądź „społeczeństwo obywatelskie”. Na podstawie tego autor wyznaczył dwa poziomy partycypacji. Pierwszy z nich to udział obywateli w życiu publicznym, np. w postaci uczestnictwa w wyborach czy referendach, drugi zaś - wykształcenie się ze społeczeństwa formalnych bądź nieformalnych grup, które dzięki swojej aktywności mogą zwiększyć efektywność działań partycypacyjnych [Siemiński 2007: 37-38]. Wiąże się to bezpośrednio ze zmianami, jakie zachodzą 
w podejściu do zarządzania publicznego. W wyniku dostrzeżenia wad systemu biurokratycznego ${ }^{6}$, jak również ułomności zastępczej koncepcji New Public Management ${ }^{7}$, obecnie przełomową stała się idea współrządzenia (local governance) bądź analogicznie - koncepcja dobrego rządzenia (good governance). Charakterystyczną cechą modelu jest umożliwienie obywatelom sprawowania władzy zarówno w procesie podejmowania, jak i wdrażania decyzji przy odpowiednim instrumentarium upowszechniającym ideę demokracji deliberacyjnej. Innymi słowy model ten cechuje się nowym podejściem do aktorów politycznych uznawanych pierwotnie za podmioty polityki, aktualnie zaś - za partnerów w podejmowaniu i wdrażaniu decyzji [Sowada, Kotus 2015: 47]. Istotę tego ujęcia przedstawia rekomendująca ideę good governance Organizacja Narodów Zjednoczonych, wskazując za meritum osiem jej założeń: 1) uczestnictwo w życiu publicznym wszystkich członków społeczeństwa obywatelskiego (równa dostępność), jak również rzeczywistą wolność zrzeszania się oraz zbiorowe i indywidualne prawo do wyrażania opinii; 2) praworządność, której założeniem jest rządzenie na podstawie i w gruncie prawa zapewniającą równość wszystkich członków społeczeństwa wobec praw człowieka, obywateli i praw mniejszości; 3) przejrzystość, oznaczającą podejmowanie i wdrażanie decyzji publicznych na podstawie klarownych zasad i procedur, zachowując przy tym jawność informacji; 4) obowiązek instytucji publicznych w postaci bezzwłocznego - w miarę możliwości - reagowania na potrzeby wszystkich mieszkańców; 5) dążenie do konsensusu jako nadrzędnej wartości służącej dobru wspólnemu; 6) inkluzywność, czyli możliwość wpływania na proces rządzenia bądź poczucie takiej możliwości wśród społeczeństwa, czego istotą jest nastawienie na budowanie spójności społecznej i braku poczucia wykluczenia wśród lokalnej społeczności; 7) skuteczność i efektywność rządzenia, które odpowiada na potrzeby społeczne najlepszym i najtańszym kosztem; 8) odpowiedzialność wykonawców zadań publicznych, tj. instytucji publicznych,

6 Koncepcja fachowej, zhierarchizowanej i efektywnej administracji publicznej została opracowana przez wybitnego teoretyka M. Webera, którą autor nazywał biurokracją idealną. Koncepcja ta w głównej mierze cechowała się sztywnością i hierarchicznością szczebli organizacji, depersonalizacją urzędników, bezosobowymi przepisami, jak też formalnymi kryteriami kwalifikacji, awansu zawodowego oraz wynagrodzenia. Równie istotną właściwością była specjalizacja, skuteczność i precyzyjne określenie zakresu zadań i obowiązków. M. Weber porównał stworzony model do maszyny, uznając, iż specjalizacja tak skonstruowanej administracji zwiększa jej produktywność, a depersonalizacja systemu tworzy warunki służące przyspieszeniu procesów decyzyjnych. W rzeczywistości jednak system biurokratyczny okazał się pełnym niedoskonałości, m.in. przez nieograniczony rozrost i ciągłą potrzebę tworzenia nowych struktur, brak sensownego pomiaru wydajności organizacji biurokratycznej czy też powstawanie nieformalnych grup interesów [Przywojska 2016: 83-85].

7 Alternatywą dla wadliwej idei M. Webera był model menadżerskiego zarządzania publicznego New Public Management. Podstawowymi zasadami tej koncepcji było wprowadzenie mechanizmów rynkowych, traktowanie społeczeństwa jako klienta administracji, decentralizacja zarządzania organizacjami, odpowiedzialność za wyniki, regulacja procesów dostarczania usług publicznych, oddzielenie procesów zarządzania od czynności politycznych czy też zliberalizowanie warunków pracy i płac. W perspektywie czasu okazało się jednak, iż narzędzia zarządcze i organizacyjne zwiększające efektywność nie mogą być stosowane równorzędnie w biznesie i sektorze publicznym [Przywojska 2016: 86-87]. 
sektora prywatnego, organizacji pozarządowych czy wolnych mediów względem całego społeczeństwa [United Nations, Economic and Social Commission for Asia and the Pacific: 2-3]. Każda z przedstawionych zasad jest istotna, jednak w celu zaistnienia dobrego rządzenia konieczna jest realizacja całego zbioru założeń. W rzeczywistości można jednak dostrzec idealizację tak zdefiniowanej idei, chociażby ze względu na bezkonfliktowość czy pełny kompromis, co z całą pewnością jest dość utopijne. „Model ten jednak należy rozumieć aproksymatywnie: każde zbliżenie się do zarysowanego ideału jest wartościowe. Model ten pokazuje zatem nie tyle zamierzony stan, co kierunek dążeń" [Przywojska 2016: 88].

Powyższe jednoznacznie wskazuje, że zmieniające się potrzeby i wyzwania w obliczu dynamicznego rozwoju społeczno-gospodarczego zwiększają rolę społeczeństwa w sprawowaniu władzy. Współcześnie jest to najbardziej pożądany kierunek rządzenia miastami, czego wyrazem jest właśnie partycypacja społeczna. Termin ten jednak przyjmuje różne brzmienia, wprowadzając chaos definicyjny. Należy więc zaznaczyć, że samo zapewnienie informacji mieszkańcom czy też przedstawienie publicznych obaw i potrzeb w celu podjęcia adekwatnych decyzji przez włodarzy nie jest oczekiwaną partycypacją. Społeczeństwo bowiem winno być zarówno podmiotem, jak i uczestnikiem (w tym przypadku procesu rewitalizacji), co oznacza zorganizowane i realne zaangażowanie w każdy z jego etapów. Co więcej partycypacja ma na celu zaistnienie interakcji pomiędzy społeczeństwem a władzami, generując potencjalną współpracę [Creighton 2005: 7].

W celu uporządkowania terminu partycypacji społecznej powstało wiele narzędzi i koncepcji. Jedną z najpopularniejszych jest „drabina partycypacji” autorstwa Sherry Phyllis Arnstein ${ }^{8}$ [1969: 217], która wskazała stadium przejściowe między tzw. „pustym rytuałem partycypacji” a faktycznym uczestnictwem obywateli i wykształceniem się władzy obywatelskiej. Autorka przedstawiła swoje rozważania w postaci ośmiu szczebli partycypacji, które zostały podzielone na trzy główne kategorie: nie-partycypację, tokenizm ${ }^{9}$ i władzę obywatelską. Ponadto wskazała, że osiągnięcie najwyższego stopnia (władzy obywatelskiej) jest właśnie oddolnym zarządzaniem miastem, zaś pierwszy ze stopni (nie-partycypacja) skutkuje manipulacją społeczności miejskich i pozorowaną ich edukacją, które są efektem osiągnięcia większego poparcia przez władze. Równie ciekawym podejściem do tego zagadnienia jest koło partycypacji Scotta Davidsona mające na celu zdefiniowanie sposobu i stopnia włączenia społecznego $\mathrm{w}$ procesie planowania i wdrażania planów rozwojowych. Uspołecznienie procesu planowania (inclusive planning) w tym modelu to cztery części koła oznaczające poszczególne jej wymiary: informację, konsultację, partycypację i upodmiotowienie (empowerment). Każdy z nich został dodatkowo podzielony na

8 Artykuł A ladder of citizen participation autorstwa S.R. Arnstein z 1969 roku współcześnie uznawany jest za jedną z fundamentalnych prac na temat partycypacji społecznej.

9 Pojęcie „tokenizm” należy rozumieć jako praktykę czynienia symbolicznych starań w celu włączenia przedstawicieli grup niszowych do instytucji. Inaczej rzecz ujmując, jest to tworzenie fałszywego wrażenia równości statusu społecznego. 
trzy kategorie działań cechujące się mniejszym lub większym poziomem włączenia w procesy planowania. Warto jednak dodać, że autor tego modelu nie traktuje zarówno informacji, jak i konsultacji jako partycypacji społecznej. Uważa, że są to bierne formy zaangażowania społeczności lokalnych [Sowada, Kotus 2015: 40-42]. Zupełnie odmienną koncepcją jest natomiast teoria uczenia się sytuacyjnego przez działanie według Etienne’a Wengera. W tym zaś przypadku aktywność i tożsamość społeczna, zaufanie czy zaangażowanie w sprawy wspólnoty są nie tyle metodą, co procesem. Polega on na nabywaniu umiejętności i kompetencji społecznych w trakcie biernego, przez obserwację i naśladownictwo, jak i aktywnego uczestnictwa, przejawiającego się świadomym przekazywaniem norm społecznych. W tenże sposób, który wymaga długofalowych działań, możliwe jest wyuczenie demokracji lokalnej w działaniu. Tego rodzaju zabiegi mogą, a wręcz powinny być realizowane w trakcie edukacji młodzieży szkolnej w celu przysposobienia partycypacyjnych zasad funkcjonowania we wspólnocie [Sowada, Kotus 2015: 42-43]. Innym, interesującym rozwiązaniem generującym prawidłowy przebieg współpracy w mieście jest także koncepcja partycypacyjnej triady miejskiej „mieszkańcy - stowarzyszenia i ruchy miejskie - władze lokalne”, która jest autorską propozycją Tomasza Sowady i Jacka Kotusa [2015: 44-45]. W tym z kolei przypadku istotą są stowarzyszenia lokalne pełniące rolę pomostu między mieszkańcami a władzami, tym samym współpracujące i kontrolujące poczynania rządzących miastami. $Z$ jednej strony umożliwi to bowiem reprezentację interesów mieszkańców, z drugiej zaś - budowę pozytywnych postaw obywatelskich i zaangażowania społecznego. Autorzy podkreślili, że pierwszą fazą procesu uspołecznienia winno być stworzenie warunków dla zrzeszania się różnolitych stowarzyszeń i ruchów miejskich nieprzenikających do struktur władzy, a będących niezależnymi uczestnikami współpracy. Wówczas zgodnie z założeniem tego ujęcia ma nastąpić wzrost świadomości mieszkańców, którzy w końcowym etapie zaczną zrzeszać się w struktury lokalne, np. sąsiedzkie. Sformułowana w ten sposób koncepcja jest progresywnym ujęciem pod warunkiem, że wspomniane stowarzyszenia i ruchy społeczne będą pełnić rolę pośrednika zaledwie w pierwszym jej etapie, a ich kluczową rolą stanie się edukacja w zakresie partycypacji i dzielenie doświadczeniami w celu zaktywizowania mieszkańców. Wówczas, gdy we wspomnianej współpracy każda z trzech grup interesariuszy stanowić będzie tak samo ważny podmiot polityczny, wtedy też procesy partycypacyjne mają szansę przynieść lepsze efekty uwzględniające fundamentalne potrzeby wszystkich mieszkańców.

Zaangażowanie mieszkańców w proces kształtowania polityki rewitalizacji miejskiej jest równoważnie zależne od samych mieszkańców, jak i postawy władz miasta. Do zadań rządzących należy z pewnością konsekwentna mobilizacja społeczności miejskich do czynnego udziału w życiu publicznym miasta oraz uświadamianie znaczenia partycypacji społecznej jako drogi do lepszych efektów w rewitalizacji. W polskich realiach jeszcze do niedawna, jak wskazał Andrzej Majer [2007: 94], rzeczywistość empiryczna była raczej krytyczna wobec modelu obywatelskiego czy demokracji deliberatywnej. Pytając respondentów, którymi byli politycy i urzędnicy 
czterech miast polskich, o to, kto winien być inicjatorem polityki miejskiej - odpowiedzi jednoznacznie wskazywały na krytyczne podejście do inicjowanych zmian w zakresie rozwoju lokalnego. Wówczas odpowiedź z wynikiem prawie $60 \%$ uzyskała ,rada miasta we współpracy z prezydentem”, natomiast ,inne podmioty”, czyli wszelkie organizacje, instytucje stowarzyszenia czy partie osiągnęły wynik zaledwie piętnastoprocentowy. Obserwacje obecnej praktyki życia miejskiego pozwalają jednak dostrzec znaczne zmiany w tym zakresie. Co prawda procesy partycypacyjne wciąż nie są prowadzone z należytą starannością, czego dowodzą liczne badania na ten temat, niemniej stają się normą w polskiej polityce rewitalizacyjnej. Podłożem takiego stanu rzeczy jest zapewne krótkotrwały czas realizacji działań partycypacyjnych, co jednoznacznie wiąże się z brakiem należytego doświadczenia. W związku z tym badania na temat wykorzystywanych w Polsce narzędzi partycypacyjnych również nie są zbyt optymistyczne. Jedne z nich prowadzone pod kierunkiem Anny Olech [2012: 9-11] dowodzą, że najczęstszymi są: informowanie o podjętych decyzjach $(99 \%)$, ich wyjaśnianie $(60 \%)$ oraz konsultowanie $(80 \%)$. Z kolei odnośnie do aktywizacji mieszkańców $-31 \%$ z respondentów wykazało włączenie się w procesy decyzyjne, jednak aż 66\% z nich deklarowało zainteresowanie w tym zakresie ${ }^{10}$. Do podobnych wniosków zbliżyły się analizy Waldemara Siemińskiego i Teresy Topoczewskiej [2009: 53-54], badających m.in. działania z zakresu partycypacji społecznej w rewitalizacji. Otrzymane wyniki jednoznacznie wskazują, że najbardziej renomowaną formą jest informowanie, a w dalszej kolejności przeprowadzanie konsultacji (najczęściej w postaci badań sondażowych). Analizy o podobnym zakresie, choć w znacznie większej skali przeprowadził Aleksander Noworól, Kamila Noworól i Paweł Hałat ${ }^{11}$ [2012: 34-39]. Również w tym przypadku podstawowymi technikami okazało się informowanie i przeprowadzanie konsultacji. Jeśli chodzi o techniki informowania społeczeństwa, najpopularniejszą było informowanie za pośrednictwem własnych stron WWW (90\%), prasy lokalnej (75\%) oraz mediów elektronicznych (58\%). W przypadku konsultacji społecznych jako jednej z podstawowych metod partycypacyjnych zbadano pod kątem pozyskiwania informacji na temat potrzeb i opinii mieszkańców miast, gdzie najpopularniejszą metodą okazały się ankiety wśród mieszkańców (blisko 50\%). Najczęściej stosowanymi technikami włączającymi mieszkańców w proces rewitalizacji okazały się zaś projekty podmiotów prywatnych i społecznych (83\%) oraz konsultacje społeczne w postaci otwartych spotkań z mieszkańcami (56\%) oraz spotkań z potencjalnymi beneficjentami (53\%).

Przybliżone powyżej analizy wskazują jednoznacznie, iż w zakresie polskiej rewitalizacji stosowane są z reguły tradycyjne narzędzia partycypacyjne, a samo

${ }^{10}$ Przedstawione badania stanowią wyniki w kwestii partycypacji społecznej w wymiarze ogólnym, niedotyczącym wyłącznie procesów rewitalizacyjnych w Polsce. Niemniej obrazują intensywność wykorzystywanych narzędzi oraz faktyczny stan zaangażowania obywateli w procesy decyzyjne.

${ }^{11}$ Przytoczone pokrótce analizy zostały sporządzone na podstawie Lokalnych Programów Rewitalizacji (LPR), zamieszczonych w Biuletynach Informacji Publicznej przez 190 miast polskich. Badania dotyczyły wykorzystywanych do celu rewitalizacji technik i narzędzi partycypacji społecznej. 
pojęcie partycypacji w rozumieniu władz miejskich zdaje się być bardziej obowiązkiem aniżeli szansą na wypracowanie oczekiwanych rezultatów i poprawy jakości życia w mieście. Taki stan rzeczy determinuje konieczność wskazania prawidłowego ujęcia partycypacji na rzecz trwałej aktywizacji mieszkańców, integracji, budowy tożsamości miejsca, jak też samoorganizacji i współdziałania na rzecz wspólnoty miejskiej. Tylko wówczas możliwe jest osiągnięcie zamierzonych efektów przedsięwzięć rewitalizacyjnych.

\section{INKLUZJA SPOŁECZNA JAKO PRIORYTET REWITALIZACJI MIAST}

Uspołecznienie procesu rewitalizacji jest także związane z dążeniem do inkluzji społecznej, która z perspektywy jej priorytetów winna być podstawowym kierunkiem działań zmierzających do ograniczenia zjawiska wykluczenia społecznego ${ }^{12}$. Koncentracja przestrzenna biedy i marginalizacji społecznej jest bowiem niebezpieczeństwem, które przyczynia się nie tylko do upadku wspólnoty czy gorszej jakości sąsiedztwa. W perspektywie lat zła reputacja osiedla bądź dzielnicy i zwiększenie poczucia zagrożenia może skutkować całkowitą degradacją przestrzeni miasta. Przypuszczalnie istnieje także możliwość przekroczenia $\mathrm{w}$ danej przestrzeni krytycznego progu negatywnych zjawisk społecznych, co z kolei może być przyczyną utworzenia się tzw. enklawy biedy czy też getta ${ }^{13}$. Następstwem tego jest trwała segregacja i odizolowanie takiego obszaru [Przywojska 2016: 54-58].

Zdegradowane dzielnice miejskie z reguły są koncentracją przestrzenną wielu problemów społecznych, tj. ubóstwa, bezrobocia czy dezorganizacji społecznej, co wymaga podjęcia działań włączających. Proces rewitalizacji w tym przypadku obliguje do wypracowania partnerstwa, które jest trudnym wyzwaniem z uwagi na często niski poziom kapitału społecznego. Dodatkową barierą jest brak wzorów aktywności społecznej. Dlatego też proces planowania projektu rewitalizacyjnego winno poprzedzać stworzenie tzw. profilu społeczności wskazującego zarówno najpilniejsze potrzeby mieszkańców takiego obszaru, jak i zasoby społeczności miejskiej oraz jej potencjał. W tym przypadku dokonanie wyłącznie diagnozy pro-

${ }^{12}$ Wykluczenie społeczne jest to ,doznawany przez jednostkę lub grupę faktyczny brak możliwości lub znaczne utrudnienie pełnienia ról społecznych dostępnych dla innych, nawiązywania normalnych relacji społecznych, korzystania z dóbr publicznych i infrastruktury społecznej, gromadzenia zasobów i zdobywanie dochodów w godny sposób. Wykluczona społecznie jest jednostka lub grupa, która w sensie formalnym należy do danego społeczeństwa i chce uczestniczyć w jego życiu czynnie, lecz nie może z powodów będących poza jej kontrolą". Z kolei włączenie społeczne definiuje się jako realną możliwość uczestnictwa we wszelkich relacjach społecznych i korzystanie z nich według potrzeb jednostki [Przywojska 2016: 57].

${ }^{13}$ Równie niebezpiecznym zjawiskiem jest koncentracja przestrzenna osób zamożniejszych, osiedlających się w miejscach bardziej prestiżowych, spełniających oczekiwania funkcjonalne. Tak podzielone przestrzenie na rejony atrakcyjne i zdegradowane prowadzą do gettoizacji przestrzeni miejskiej i powstania miasta dualnego, o którym była już mowa we wcześniejszym fragmencie opracowania. 
blemów społecznych nie jest zabiegiem wystarczającym. Kluczowe jest tworzenie profilu w oparciu o jak najszersze źródła danych, w tym obserwacji terenu, dokumentacji i danych urzędowych, badań sondażowych z mieszkańcami, jak również wywiadów z ekspertami lokalnymi i analizą publikacji prasowych czy publicznych debat. Etap tak zdefiniowanych przygotowań jest bowiem niezbędny do przeprowadzenia następnego stadium rewitalizacji, jakim jest sformułowanie oceny sytuacji i we współpracy z mieszkańcami - wyznaczenie priorytetowych obszarów działań. W tym celu realizacją działań aktywizujących winni zajmować się odpowiednio wykwalifikowani profesjonaliści (community workers), którzy dysponują odpowiednią wiedzą i umiejętnościami z zakresu pracy i koordynowania działań w partnerstwie ze społecznościami lokalnymi. $Z$ reguły tak zdefiniowaną działalnością zajmują się tzw. animatorzy społeczni. Kluczowa jest jednak ich niezależność od władz miejskich, działalność bowiem pracowników ośrodków pomocy społecznej może się okazać ograniczona formalnymi regulacjami, co w rzeczywistości może spowodować konflikt interesów [Wódz 2011: 45-49]. Takie ujęcie zdaje się być dobrą praktyką, która winna być szeroko promowana. Jednym z najefektywniejszych przykładów rewitalizacji przeprowadzanych z udziałem lokalnych animatorów społecznych w warunkach polskich miast jest realizacja projektu „Fabryka Pełna Życia - rewitalizacja śródmieścia Dąbrowy Górniczej” współfinansowanego ze środków Unii Europejskiej w ramach Programu Operacyjnego Pomoc Techniczna 2014-2020. Historia modelowego przedsięwzięcia rewitalizacyjnego rozpoczęła się pod koniec 2015 roku, gdy rządzący miastem przejęli od Skarbu Państwa obszar o powierzchni 4 hektarów w północnej części śródmieścia. Pozyskany teren był obszarem zdegradowanym, dotychczas niedostępnym dla mieszkańców, na którym znajdowała się zamknięta fabryka obrabiarek Defum oraz tereny przyległe do dworca kolejowego z licznymi poprzemysłowymi halami i budynkami. Przejęcie tego terenu dało więc możliwość stworzenia nowego, wyróżniającego się centrum miasta z zachowaniem historycznych jego walorów. Tym samym narodził się pomysł na realizację projektu „Fabryka Pełna Życia”, którego założeniem jest ukształtowanie otwartej przestrzeni publicznej o zróżnicowanym zagospodarowaniu funkcjonalno-przestrzennym. Co jednak najistotniejsze, przedsięwzięcie wyróżnia się spośród innych tego rodzaju inwestycji w realiach polskich tym, że zarówno sam koncept tego miejsca, jak i jego ostateczny kształt miał zostać wypracowany przy szerokiej współpracy mieszkańców, organizacji pozarządowych oraz lokalnych przedsiębiorców. W ostateczności więc projekt rewitalizacyjny centrum Dąbrowy Górniczej jest autorską koncepcją mieszkańców. Dzięki wykorzystaniu spacerów badawczych, mobilnych punktów konsultacyjnych, debat podwórkowych czy drzwi otwartych Fabryki konsekwentnie poznawano wizje i oczekiwania mieszkańców wobec nowego centrum. Dużą rolę $\mathrm{w}$ tym odegrali także lokalni animatorzy rewitalizacji. W trybie konkursowym wyłoniono bowiem ośmiu animatorów dzielnicowych, których zadaniem było świadome uczestnictwo w procesie rewitalizacji „Fabryki Pełnej Życia”, jak również reprezentacja pomysłów mieszkańców i innych interesariuszy. W efekcie ich pracy, 
dzięki przeprowadzeniu sondaży ulicznych, spotkań otwierających, Dzielnicowych Forów Mieszkańców, elektronicznych kart pomysłów i map interaktywnych, stale monitorowano nastroje społeczne, nawiązano współpracę ze społecznością miejską, rekomendując przy tym wiele cennych wskazówek dla dalszych etapów rewitalizacji Fabryki. Co równie istotne, na jej terenie wspólnie z partnerami społecznymi i instytucjonalnymi organizowane są liczne wydarzenia kulturalne, jarmarki, festiwale, letnie kino plenerowe, warsztaty czy pikniki adresowane do wszystkich grup społecznych Dąbrowy: dzieci, rodzin, seniorów, ludzi młodych i osób niepełnosprawnych. Ponadto w Fabryce powstał także ogród społeczny. Tym samym rządzący miastem umożliwili mieszkańcom korzystanie z tej przestrzeni jeszcze przed zakończeniem pełnej rewitalizacji, zachęcając do współpracy i ożywiania nowego centrum. Przy zaangażowaniu mieszkańców i licznych interesariuszy teren dawnej fabryki przekształcany jest zatem w przyjazną przestrzeń publiczną, która w przyszłości ma stanowić wizytówkę Dąbrowy Górniczej, ukazując również przemysłowe tradycje miasta. Nowo powstająca przestrzeń ma być niezwykle funkcjonalno-użytkowym miejscem, w którym mają się znajdować pasaże wewnętrzne i zewnętrzne, kluby muzyczne, lokale gastronomiczne, lokalny browar, hala targowa, centrum biznesowe, centrum sportów wypoczynkowych, a także rynek Fabryki i amfiteatr. Poza tym konieczna jest przebudowa układu komunikacyjno-drogowego i zadbanie o ciągi piesze, uwzględniając specyficzne potrzeby seniorów i osób niepełnosprawnych. Wypracowana koncepcja społeczna uwzględnia więc potencjał poprzemysłowych budynków i hal, a nowe centrum ma stanowić przestrzeń rozwoju, innowacji i rekreacji. Wszystko wskazuje więc na wielki sukces tak zorganizowanego przedsięwzięcia rewitalizacyjnego [Fabryka Pełna Życia].

Dynamiczne przemiany, nieznane wcześniej zjawiska i wyzwania, których obecnie doświadczamy, powodują, że kwestia społecznej inkluzji nabiera nowego znaczenia. Pogłębiająca się obecnie decentralizacja i kooperacja podmiotów lokalnych stanowi istotny sprawdzian dla rządzących miastami w zakresie praktyki rewitalizacji. „Celem projektowania dla wszystkich jest takie zorganizowanie przestrzeni, aby stała się przyjazna i dostępna dla mieszkańców. Zasadą powinno być uwzględnienie potrzeb różnych grup osób: starszych, niepełnosprawnych, rodzin z dziećmi, kobiet i mężczyzn (age-friendly environment)" [Rządowy Program na rzecz Aktywności Społecznej: 28]. W związku z tym coraz częściej podejmowane są w Polsce inicjatywy oparte na inspirujących doświadczeniach zagranicznych, czego dowodem jest idea budownictwa wielopokoleniowego. Realizacji tego pomysłu na wzór dobrych praktyk z Niemiec, Holandii czy Szwajcarii podjęło się miasto Łódź (Dom Wielopokoleniowy przy ul. Wólczańskiej 168) oraz Warszawa (Kamienica Wielopokoleniowa przy ul. Stalowej 29). Celem innowacyjnego modelu mieszkaniowego jest budowa silnej więzi sąsiedzkiej, wzajemnej pomocy, tożsamości miejsca, jak również poprawa jakości życia potencjalnych mieszkańców i estetyki miasta ( $\mathrm{z}$ uwagi na rewitalizację w tym celu pustostanów miejskich). By osiągnąć powyższe, kluczową cechą budownictwa wielopokoleniowego jest jego 
zróżnicowanie społeczne, a więc dobór mieszkańców w myśl „miksu społecznego” uwzględniającego zarówno osoby młode, seniorów, jak i osoby z niepełnosprawnościami i rodziny z dziećmi. Ponadto w obiektach lokalizowane są pomieszczenia zwiększające jego funkcjonalność i umożliwiające włączenie społeczne. O celu ich przeznaczenia, zgodnie z potrzebami społecznymi, często decydują sami mieszkańcy w prowadzonych w tym zakresie konsultacjach społecznych. Najczęściej są to gabinety lekarskie, miejsca do rehabilitacji, świetlice, inkubatory przedsiębiorczości zawodowej, usługi gastronomiczne, a nawet sklepy. W celu integracji gospodarowana jest natomiast przestrzeń ogólnodostępna w postaci klubów sąsiedzkich bądź ogrodów społecznościowych. Miejsca te powstają z myślą o budowie poczucia przynależności, dlatego też są prowadzone przez wszystkich mieszkańców zgodnie z ich wspólną ideą [Przywojska 2016: 78-79].

\section{UWARUNKOWANIA POLSKIEJ POLITYKI REWITALIZACJI W KONTEKŚCIE PARTYCYPACJI}

Dostrzeżenie potrzeby społecznego uczestnictwa w polskiej rewitalizacji było procesem stosunkowo długim, którego brak wywołał negatywne skutki dotychczasowych zabiegów „naprawy” przestrzeni miast. Konieczność zahamowania niekontrolowanego ich rozwoju (tzw. proces suburbanizacji bądź rozlewanie się miast), uatrakcyjnienia centralnych przestrzeni miejskich, jak również uwzględnienia nowego, wielowymiarowego podejścia do odnowy miast w ostateczności zobligował władze centralne do nowelizacji przepisów prawnych w zakresie rewitalizacji. Dotychczas procesy rewitalizacyjne były prowadzone na podstawie Ustawy o samorządzie gminnym, mimo że nie były unormowane prawnie, jak również nie stanowiły zadania własnego gminy. W zakresie partycypacji jedynymi wówczas zapisami były regulacje umożliwiające przeprowadzanie konsultacji społecznych. Wątek partycypacyjny został nadmieniony dopiero w roku 2003, kiedy w życie weszła Ustawa o działalności pożytku publicznego i o wolontariacie rekomendująca współpracę organów władz z organizacjami pozarządowymi i instytucjami pożytku publicznego. W dokumencie wskazano także możliwość składania wniosków dotyczących rewitalizacji w ramach inicjatywy lokalnej oraz nieliczne sytuacje obligujące władze do przeprowadzenia konsultacji społecznych, nadając im charakter fakultatywny. Niestety w zapisach zabrakło nakreślenia warunków realizacji tego rodzaju działania [Ustawa o działalności pożytku... 2003]. Formy partycypacji społecznej w rewitalizacji i związanych z tym podstaw prawnych zapewniła jednak Ustawa z dnia 27 marca 2003 r. o planowaniu i zagospodarowaniu przestrzennym. Prawodawca wprowadził bowiem obowiązek dyskusji publicznej w poszczególnych procedurach planistycznych, a także możliwość składania wniosków i uwag do danego projektu [Szlachetko 2018: 154]. Ponadto nałożył obowiązek informacyjny na wójta, prezydenta bądź burmistrza miasta w procesie sporządzania, a także uchwalania miejscowego planu zagospo- 
darowania przestrzennego i miejscowego planu rewitalizacji. Niemniej jednak zabrakło warunków formalnych w kwestii szczegółowego przebiegu wspomnianych działań partycypacyjnych, a same wnioski nie mają charakteru wiążącego [Ustawa o planowaniu i zagospodarowaniu przestrzennym 2003].

Długo oczekiwaną i dobrze rokującą, jak też aktualizującą dotychczasowe postrzeganie rewitalizacji w Polsce miała być uchwalona w 2015 roku Ustawa o rewitalizacji. Tymczasem znowelizowane przepisy prawne wciąż budzą obawę w kontekście jakości polskiego prawa $\mathrm{w}$ tym zakresie. $\mathrm{W}$ dokumencie $\mathrm{z}$ pewnością brakuje wyjaśnienia wielu stosownych pojęć, a ustawodawca wydaje się nie dostrzegać kluczowych dla tego procesu uwarunkowań i generowanych problemów. Ustawa $\mathrm{w}$ istocie jest dokumentem wskazującym w głównej mierzej planowanie działań rewitalizacyjnych w gminie, nie precyzując kolejnych jej etapów - realizacji projektów i ich oceny. Wciąż nie sprecyzowano także rozwiązań dotyczących decydujących kwestii w postaci polityki rewitalizacyjnej, finansowania i realizacji konkretnych projektów czy wskazania metod rozwiązujących bieżące problemy miast w Polsce. Zadawalające jest jednak uwzględnienie pożądanego uspołecznienia procesu rewitalizacji. Co prawda ustawodawca partycypację społeczną uważa za „aktywny udział interesariuszy”, wśród których wymienia w zasadzie wszystkich mieszkańców i osoby realizujące cele własne na terenie danej gminy, to pojęcie te wpisał w najważniejsze zasady rewitalizacji [Parysek 2016a: 15]. Wskazał też, iż uczestnictwo społeczne należy uwzględnić w każdym etapie rewitalizacji - przygotowaniu, realizacji, a także monitoringu i ewaluacji, nadając temu charakter obligatoryjny i zabezpieczając partycypację sankcjami nieważności. Ustawodawca unormował w tym przypadku dwie formy uczestnictwa - konsultacje społeczne i komitet rewitalizacji. Choć pierwsza z nich nie stanowi novum w działalności gmin, to realizuje zasadę komunikacji dwustronnej jako istoty dialogu społecznego. Tym razem zostały też wskazane formy prowadzenia konsultacji, wśród których wymienił uwagi w postaci papierowej i elektronicznej, jak też spotkania z mieszkańcami, debaty, warsztaty, spacery studyjne, ankiety, wywiady, wykorzystanie grup przedstawicielskich czy zbieranie uwag ustnych. W zapisach zabrakło jednak metod i instrumentów ich przeprowadzania. Drugą z kolei formę realizacji zasady partycypacji w procesach rewitalizacyjnych - komitet rewitalizacji - wprowadzono w celu gwarancji właściwego i merytorycznego przygotowania działań rewitalizacyjnych. Wprawdzie nie posiada on uprawnień władczych, ale ma pełnić funkcję opiniodawczo-doradczą. W Ustawie o rewitalizacji wskazuje się także, że wszelkie działania inicjujące rewitalizację gmina ma realizować „,W sposób zapobiegający wykluczeniu mieszkańców obszaru rewitalizacji z możliwości korzystania z pozytywnych efektów procesu rewitalizacji, w szczególności w zakresie warunków korzystania z gminnego zasobu mieszkaniowego" [Ustawa o rewitalizacji 2015]. Jednak zapewnienie powyższego jest dość problematyczne z uwagi na proces gentryfikacji. W przypadku procesów rewitalizacyjnych przestrzeni mieszkalnych skutkiem z reguły są wyższe koszty czynszu mieszkaniowego czy rozbieżności o charakterze socjologiczno-kulturowym, co z całą pewnością nie sprzyja inkluzji społecznej. 
Uwzględnienie przedstawionych rozważań pozwala dostrzec, iż polskie prawo w zakresie rewitalizacji wymaga jeszcze wielu doprecyzowań ${ }^{14}$. Uspołecznienie procesu rewitalizacji w myśl długo oczekiwanej ustawy stanowi ważny jej komponent, jednak obowiązki nałożone na władze lokalne są jeszcze zbyt fragmentarycznie zdefiniowane. Faktem jest, że akt ten wprowadza pewne pozytywne zamiary w postaci regulacji kwestii rewitalizacyjnych w ramach jednego dokumentu, uznania tego procesu za zadanie własne gminy, określenia podmiotów realizujących projekty, jak też warunków współpracy i zasad partycypacji społecznej [Parysek 2015: 22]. Jednak w dalszym ciągu są to podstawowe metody służące włączeniu społeczności miejskich w zarządzanie procesem rewitalizacji, tworzące katalog minimalnych reguł prawnych. Należy też podkreślić, że proces partycypacji w ustawie jest wysoce zbiurokratyzowany, czego następstwem może być nie tylko zniechęcenie społeczności na rzecz aktywnego uczestnictwa i taktowanie postanowień ustawowych przez rządzących jako obowiązku, który po prostu należy wykonać, ale też poniesienie dodatkowych kosztów przez gminy. Niemniej jednak skuteczna partycypacja społeczna w warunkach polskich miast w zakresie prawa jest wciąż ogólnikowo nakreśloną zasadą rewitalizacji. Wydaje się, że bardziej zależną od determinacji włodarzy miast w celu uzupełnienia obowiązkowych metod partycypacyjnych, jak również w celu podniesienia efektywności realizowanej w polskich miastach polityki rewitalizacji aniżeli ustawowo określonych norm prawnych.

\section{ZAKOŃCZENIE}

Realizowane w Polsce programy rewitalizacyjne, jak wskazuje raport Najwyższej Izby Kontroli, z reguły są prowadzone w sposób niekompleksowy, przynosząc wymierne rezultaty ${ }^{15}$. Wśród najczęściej popełnianych błędów wskazuje się brak spójności wdrażanych programów, w tym nieeliminowanie negatywnych zjawisk

${ }^{14}$ Za podstawę skutecznej realizacji projektów rewitalizacyjnych, wskazywanych w literaturze przedmiotu, uznaje się w pierwszej kolejności prawidłowo ustanowione prawo oraz dostępność środków finansowych [Parysek 2016a: 11]. Te pierwsze są przedmiotem rozważań niniejszego opracowania, zaś drugie - wciąż nie zostały ustawowo określone. Pierwszym dokumentem, który rzeczywiście uwzględnia te kwestie, jest Krajowa Polityka Miejska 2023. W sporządzonej przez Ministerstwo Infrastruktury i Rozwoju strategii wskazano trzy procesy planowania i programowania rewitalizacji. Wraz z określeniem wizji i koncepcji dla zdegradowanego obszaru i analizy doboru odpowiednich rozwiązań uwzględniono określenie źródeł finansowania działań rewitalizacyjnych. W dalszych zapisach opisano dostępne źródła finansowania tych przedsięwzięć, wśród których za najbardziej znaczące do 2020 roku wskazano fundusze europejskie wydatkowane w ramach Umowy Partnerstwa. Co ważne również, w przytoczonym dokumencie dużo uwagi poświęcono kwestii społecznej. Już w definicji uwzględniono bowiem, że w kompleksowej rewitalizacji „należy wypracować przedsięwzięcia całościowe (integrujące interwencję na rzecz społeczności lokalnej, przestrzeni i lokalnej gospodarki), skoncentrowane terytorialnie i powstające we współpracy z lokalną społecznością" [Krajowa Polityka Miejska: 56-60].

${ }^{15}$ Wyniki raportu dotyczą działań rewitalizacyjnych prowadzonych w latach 2007-2015 w pięciu województwach. 
społecznych i nienależytą poprawę warunków życia mieszkańców, ograniczanie działań do realizacji pojedynczych projektów lub wyłącznie zmian infrastrukturalnych (mimo zdiagnozowanych problemów społecznych). Poza tym należy nadmienić nieskuteczne mechanizmy oceny działań rewitalizacyjnych, a nade wszystko - realizację przedsięwzięć rewitalizacyjnych wyłącznie przez jednostki samorządowe oraz brak w tym procesie uczestnictwa społeczności lokalnej [Rewitalizacja zdegradowanych obszarów miast 2015: 8-14]. Taki stan rzeczy jest uwarunkowany nie tylko dotychczasowym deficytem stosownych zapisów prawnych, ale przede wszystkim brakiem doświadczenia pracowników samorządowych w inicjowaniu kompleksowych i efektywnych działań rewitalizacyjnych, deficytem zwerbalizowanych schematów współpracy oraz niskiego poziomu wiedzy wśród społeczności miejskich w zakresie istotności współdziałania. Realizacja skutecznej współpracy podmiotów polityki rewitalizacyjnej w dużej mierze wymaga ich świadomości, przygotowania, odpowiednio zaplanowanych procesów, lecz nade wszystko - społecznego zaangażowania i włączenia $w$ ten proces wszystkich beneficjentów. Tym samym fundamentalną zasadą realizacji programów rewitalizacyjnych jest zjawisko upodmiotowienia ( $\mathrm{em}$ powerment). Przyrost politycznej kompetencji i wartości, który generuje poczucie sprawstwa i chęć poprawy własnej sytuacji, sprawia, że mieszkańcy miast stają się niezbędnymi aktorami w polityce rewitalizacji miejskiej [Przywojska 2016: 127]. W tym miejscu należy też podkreślić istotność małych inicjatyw lokalnych, włączających i angażujących mieszkańców jako aktorów rewitalizacji [Gierszewski 2017: 309]. To właśnie tego rodzaju aktywności, które niekoniecznie muszą być działaniami formalnymi, stają się z reguły bodźcem do dalszych działań. Przez pomyślną realizację lokalnej zmiany społecznej następuje bowiem wzmocnienie więzi między grupami bądź jednostkami, co sprzyja poprawie ich sytuacji. W efekcie następuje podniesienie jakości życia mieszkańców jako priorytetowego celu mieszkańców i rządzących, czyli rozwoju społeczności lokalnej. By zainicjować jednak zmiany odnośnie do tak pojmowanej polityki rewitalizacyjnej, konieczne jest przeprowadzenie zabiegów edukacyjnych, przeglądu efektownych doświadczeń zagranicznych i krajowych, a tym samym wskazanie możliwych do podjęcia inicjatyw. Stąd też zasadna wydaje się być koncepcja miejskiej triady, wskazująca rolę stowarzyszeń i ruchów miejskich jako siły napędowej dla korzystnych zmian w tym zakresie, a w przypadku włączenia osób wykluczonych - wpływu animatora społecznego. Jednak należy pamiętać, że „upodmiotowienie współczesnego mieszkańca miasta to akceptowanie jego wolnej woli i dobrowolności działania, podmiotowość tegoż obywatela z kolei to jego poczucie sprawstwa wynikające z przekonania posiadania takiej wolnej woli i możliwości podjęcia dobrowolnie działania" [Kotus 2018: 123].

Partycypacja i włączenie społeczne stanowią ważny komponent procesu rewitalizacji z uwagi na unikatową wiedzę mieszkańców i innych podmiotów w zakresie potrzeb, potencjałów i lokalnych zasobów. Jak wskazują jednak doświadczenia polskie, najchętniej podejmowanymi przez miejskie władze działaniami partycypacyjnymi są informowanie i przeprowadzanie konsultacji. Tego typu działania uznawane są 
jednak za najmniej wymagające formy czy nawet - jak wskazują wcześniejsze rozważania - bierne narzędzia aktywizujące. Stosowanie wyłącznie tego rodzaju metod z pewnością nie stanowi podstaw do podjęcia koniecznych działań mobilizacyjnych. Co prawda w polskich miastach obserwuje się coraz większe upowszechnianie nowoczesnych metod scalających inkluzję i deliberację (deliberative and inclusive processes), wśród których największą popularność osiągnął budżet obywatelski ${ }^{16}$. Zadawalające są również najnowsze przykłady działań rewitalizacyjnych, określanych jako modelowe rewitalizacje miast, czego przykładem jest przytoczona w tekście rewitalizacja centrum Dąbrowy Górniczej. Nie zmienia to jednak faktu, iż dotychczas praktykowana w Polsce partycypacja i inkluzja były głównie grą polityczną bądź nieudolnym realizowaniem prawnie obligatoryjnych metod aniżeli faktycznym włączaniem mieszkańców do współudziału na rzecz efektywnej odnowy miast. Taki stan rzeczy wskazuje na konieczność inicjacji i upowszechniania nowego myślenia o rewitalizacji, edukacji i mobilizacji mieszkańców miast, zrzeszania się i aktywnej działalności nowych ruchów miejskich, z czym wiąże się cel nadrzędny - zmiana kierunku realizowanej do tego czasu polityki rewitalizacji miejskiej.

\section{BIBLIOGRAFIA}

Arnstein, S.R. 1969. A ladder of citizen participation, „Journal of the American Planning Association”, nr 35 (4), s. 216-224. DOI: https://doi.org/10.1080/01944366908977225.

Creighton, J.L. 2005. The Public Participation Handbook. Making Better Decisions Through Citizen Involvement, Jossey-Bass A Wiley Imprint, San Francisco.

Fabryka Pełna Życia, http://fabrykapelnazycia.pl/ (dostęp: 10.04.2020).

Gierszewski, D. 2017. Znaczenie koncepcji governance w animowaniu społeczności lokalnych, „Dyskursy Młodych Andragogów", nr 18, s. 303-314.

Górski, A.S. 2018. Rewitalizacja - szansa czy zagrożenie dla społecznego obrazu przestrzeni?, „Metropolitan. Przegląd Naukowy”, nr 1 (9), s. 28-35.

Hausner, J., Górniak, J., Kołdras, S., Mazur, S., Paszkowska, R. (red.). 1999. Komunikacja i partycypacja społeczna. Poradnik, Małopolska Szkoła Administracji Publicznej Akademii Ekonomicznej, Kraków.

Jadach-Sepioło, A. 2007. Gentryfikacja miast, „Problemy Rozwoju Miast”, nr 3, s. 66-79.

Kaczmarek, S. 2015. Skuteczność procesu rewitalizacji. Uwarunkowania, mierniki, perspektywy, „Studia Miejskie", nr 17, s. 27-35.

Kotus, J. 2018. Partycypacja-aktywność - podmiotowość... Krok wstecz czy postęp rozwoju społeczeństwa obywatelskiego?, „Studia KPZK”, t. 183, s. 119-131.

Krajowa Polityka Miejska 2023, https://www.miir.gov.pl/media/11579/Krajowa_Polityka _Miejska_2023.pdf(dostęp: 18.02.2019).

Lorens, P. 2013. Równoważenie rozwoju przestrzennego miast polskich, Wydział Architektury Politechniki Gdańskiej, Gdańsk.

${ }^{16}$ Wśród tego rodzaju instrumentów należy też wymienić Kawiarnię Obywatelską, 21 century town meetings, warsztaty przyszłościowe, Deliberative Mapping, Warsztaty charlette, sądy obywatelskie, sondaż deliberatywny czy panele obywatelskie. W obecnym jednak czasie nie stanowią one popularnych metod partycypacyjnych w warunkach polskich miast. 
Majer, A. 2007, Wizje polityki miejskiej na przykładzie czterech polskich miast, [w:] Wspótczesna socjologia miasta. Wielość oglądów i kierunków badawczych dyscypliny, I. Borowik, K. Sztalt (red.), Wydawnictwo Uniwersytetu Wrocławskiego, Wrocław.

Majer, A. 2011. Odrodzenie miejskie, „Przegląd Socjologiczny”, vol. 60 (2-3), s. 29-46.

Majer, A. 2014, Odrodzenie miast, Wydawnictwo Uniwersytetu Lódzkiego - Wydawnictwo Naukowe Scholar, Łódź-Warszawa.

Noworól, A., Noworól, K., Hałata, P. 2012. Partycypacja społeczna w zarządzaniu procesami rewitalizacji, „Problemy Rozwoju Miast”, nr 1, s. 26-39.

Olech, A. (red.) 2012. Dyktat czy uczestnictwo? Diagnoza partycypacji publicznej, t. 1, Instytut Spraw Publicznych, Warszawa.

Parysek, J. 2015. Rewitalizacja miast w Polsce: wczoraj, dziś i być może jutro, „Studia Miejskie”, nr 17, s. $9-25$.

Parysek, J. 2016a. O najbliższej przyszłości rewitalizacji w Polsce: pragmatycznie i prognostycznie, „Problemy Rozwoju Miast", nr 4, s. 5-17.

Parysek, J. 2016b. Rewitalizacja jako problem i zadanie własne polskich samorządów lokalnych, „Rozwój Regionalny i Polityka Regionalna", nr 33, s. 16-35.

Przywojska, J. 2016. Rewitalizacja miast. Aspekt społeczny, Wydawnictwo Uniwersytetu Łódzkiego, Łódź.

Rewitalizacja zdegradowanych obszarów miast. Informacja o wynikach kontroli, https://www.nik.gov.pl/ plik/id,11869,vp,14240.pdf (dostęp: 24.02.2019).

Rządowy Program na rzecz Aktywności Społecznej Osób Starszych na lata 2014-2020. Dlugofalowa Polityka Senioralna $w$ Polsce na lata 2014-2020 w zarysie, https://das.mpips.gov.p1/source/Dlugofalowa $\% 20$ Polityka $\% 20$ Senioralna $\% 20 \mathrm{w} \% 20$ Polsce $\% 20$ na $\% 201$ ata $\% 202014-2020 \% 20 \mathrm{w} \% 20$ zarysie. pdf (dostęp: 22.02.2019).

Siemiński, W. 2007. Cele i zasady partycypacji społecznej w planowaniu przestrzennym - przeglad literatury, „Człowiek i Środowisko”, nr 31 (1-2), s. 37-59.

Siemiński, W., Topczewska, T. 2009. Rewitalizacja miast w Polsce przy wsparciu funduszami UE w latach 2004-2008, Wydawnictwo Difin, Warszawa.

Sowada, T., Kotus, J. 2015, Rola stowarzyszeń lokalnych w procesie partycypacji społecznej w zarzadzaniu miastem. Przykład Poznania, Bogucki Wydawnictwo Naukowe, Poznań.

Stawasz, D. 2017, Odnowa miasta poprzez rewitalizację, „Prace Naukowe Uniwersytetu Ekonomicznego we Wrocławiu", nr 477, s. 253-261.

United Nations, Economic and Social Commission for Asia and the Pacific, What is Good Governance?, https://www.unescap.org/sites/default/files/good-governance.pdf (dostęp: 20.02.2019).

Ustawa z dnia 24 kwietnia 2003 r. o działalności pożytku publicznego i o wolontariacie, Dz.U. 2003 nr 96 poz. 873.

Ustawa z dnia 27 marca 2003 r. o planowaniu i zagospodarowaniu przestrzennym, Dz.U. $2003 \mathrm{nr} 80$ poz. 717.

Ustawa z dnia 9 października 2015 r. o rewitalizacji, Dz.U. 2015 poz. 1777.

Wódz, K. 2011. Organizacja pracy ze społecznościa lokalna jako instrument rewitalizacji społecznej, [w:] Rewitalizacja spoleczna: od aktywizacji do rozwoju lokalnego, B. Skrzypczak, W. Łukowski (red.), Wydawnictwo Naukowe Instytutu Technologii Eksploatacji - Państwowy Instytut Badawczy, Radom.

\section{PARTICIPATION AND SOCIAL INCLUSION AS A DIMENSION OF URBAN REGENERATION POLICY}

Abstract: The article discusses the issue of the social aspect of regeneration, which should be a complex process, including in each of its stages, the broadly understood participation of local society. Stimulating this process in terms of animation and integration is a peculiarity of urban regeneration, but also a civic right and a procedure valid in democratic countries. In the conditions of Polish cities, despite the revitalization act 
adopted in 2015, the developed provisions concerning the social aspect, still raise many doubts. Therefore, using the analytical method, the author begins considerations by outlining the essence of regeneration process and indicating its optimal definition. Then, she introduces the issue of social participation, responding to the concept of local governance as a model popularizing trust, civil society and social capital. The rightness of the principle of social inclusion as the primacy of regeneration processes is also indicated. Additionally, there are interpreted the conditions of Polish urban regeneration policy in the field of social activation, analyzing the quality of legal provisions contained in the regeneration act and tools used in practice. This allows to diagnose the level of real actions for socializing regeneration processes, as well as setting out prospective measures to improve the desired results. In conclusion, the author states that it is obligatory to develop a new direction of urban regeneration policy, whose biggest drawback in the Polish reality is first of all the use of passive activating methods and limiting the empowerment of urban communities.

Keywords: regeneration, urban space, participation, co-participation, social inclusion

\section{BIOGRAM}

Martyna Rajek-Kwiatek, mgr, uczestniczka studiów doktoranckich z zakresu nauk o polityce na Wydziale Nauk o Polityce i Administracji Uniwersytetu Kazimierza Wielkiego w Bydgoszczy. Zainteresowania naukowe z dziedziny nauk politycznych to polityka miejska i kształtowanie przestrzeni miejskiej w kontekście modelu zrównoważonego rozwoju współczesnych miast w Polsce, idea współrządzenia (local governance), partycypacja i inkluzja społeczna, a także proces rewitalizacji i kwestia bezpieczeństwa w przestrzeni miejskiej. Kontakt e-mail: martyna.rajek@ukw.edu.pl. 